\title{
Pareto efficiency in the model of economy with public goods
}

\section{Pareto efikasnost u modelu privrede sa javnim dobrima} Nada Trivić *

University of Novi Sad, Faculty of Economics in Subotica, Subotica

\begin{abstract}
In order to analyze simple and complex models of market, market equilibrium and market efficiency, this article considers a more complex and realistic market model with the existence of public goods. This topic is the subject of attention of many scientists, but only recently has it been possible to apply these models on reallife situations and verify their correctness and justifiability. To understand the problems of the existence of public goods on the competitive market better, first one should first understand the nature and characteristics of public goods. Having derived Pareto efficiency criterion with the presence of public goods, the article attempts to answer the question whether there is an economy where competitive behavior may result in an efficient solution.

Keywords: competitive equilibrium, public goods, Pareto efficiency, market model

Сажетак: Ради анализе једноставних и сложених модела тржишта, тржишне равнотеже и ефикасности тржишта, у овом раду се разматра сложенији и реалистичнији модел тржишта, уз постојање јавних добара. Ова тема је предмет пажње многих научника, али тек у скорије време могуће је применити ове моделе на стварне ситуације и проверити њихову тачност и оправданост. Да би се боље разумели проблеми постојања јавних добара на компетитивном тржишту, најпре треба разумети природу и карактеристике јавних добара. Након извођења Парето ефикасног критеријума у привреди, уз присуство јавних добара, у раду се покушава одговорити на питање да ли постоји привреда у којој конкурентско понашање може довести до ефикасног решења.
\end{abstract}

Кључне речи: компетитивна равнотежа, јавна добра, Парето ефикасност, модел тржишта

\section{Introduction}

The topic of efficient resource allocation and general equilibrium has been the subject of attention of many theoreticians since the $19^{\text {th }}$ century. The general equilibrium is the possibility of simultaneous equilibrium on all markets, and purports the best possible resource use or their efficient allocation. It is first necessary to consider the definition of efficient resource allocation of the competitive market, that is, the concept of general competitive equilibrium, which was developed by long-term studying of this market model.

The earliest formalisation of this market model is ascribed to Walras (Walras, M. Esprit Léon - one of the creators of marginalist theory; established a theory of declining marginal utility; constructed the mathematical model of simultaneous equations), and is present in German literature of the 1830s. This concept reaches its maturity in the papers of Arrow (Arrow, K. Joseph - Nobel Prize for economics 1972, 
jointly with Hicks. The greatest contribution: impossibility theorem) and Debreu (Debreu, G. - Nobel Prize for economics 1983), and is called Arrow-Debreu market concept.

A much more complex and more realistic market model with the existence of public goods, introduced into the market by Samuelson (Samuelson, P. Anthony contributed to development of mathematical economy, general equilibrium and consumer behaviour theory), aiming to define under which circumstances the offer of public goods can be efficient. Later on, the topic of efficiency is dealt with by Lindahl (Lindahl, E - formulated the concept of sequential economy and intertemporal equilibrium, gave solution to resolving establishing the price of public goods), and introduced the topic of personalised price of goods. To understand the problems of existence of public goods on the competitive market better, one should first consider the nature and characteristics of public goods. This paper presents the derivation of Pareto (Pareto Vilfredo Federico Damasso - critic of cardinal utility theory and founder of ordinal; introduced the principle of compensation, defining the optimum outcome of transactions and improvement of condition in economy) efficiency criterion in nature with the presence of public goods, and the basic aim of such analysis is also to answer the question whether there is an economy where competitive behaviour can result in an efficient solution.

It can be concluded from the considered theorems that every public policy should strive to bring an economy to competitive ideal.

\section{Competitive economy model and general equilibrium concept}

The common feature of Pareto efficient allocation and complete equilibrium is the principal discovery of the modern welfare economy. Pareto-efficient outcome is a situation when the utility of a market player can be increased without reducing that of the others, and is the basic starting point of welfare theory. Equilibrium on the competitive market (Šagi, 1998, p. 53) is achieved when the influence of all forces that may induce demand or supply is annulled, that is, when demand and supply equalize.

However, a competitive system (Trivić, 2010, p. 33-42) of prices may fail (market failure) in case there are interactions between economic subjects that are not adequately reflected in the pricing system.

Any activity with external consequences on individuals of firms that did not participate in the activity, within change of costs or utility is an external. Such activities result in inequality of private and social and functions of utility costs, as changes have no reflection in market prices. Thus, prices will not bear the real level of costs of and utility required for establishing Pareto-efficient solution. 
A similar problem in prices occurs in the case of "public goods" (Williams, 2003, p. 88). These goods have two main characteristics by which they differ from the so-called private goods, that is, non-rivalry during consumption and non-excludability, which prevents their production in the private sector. The former points to the zero marginal cost, which also requires a zero price of goods, and the latter makes excluding anyone from consumption impossible. These factors are the reason while the fundamental theorem of welfare economy should be applied to the real world carefully

\section{Public goods - definition and characteristics}

To understand the problems of public goods on a competitive market, one should first understand the nature and characteristics of public goods. Public goods enable increase in utility to a larger number of users simultaneously, unlike private goods, which an enable increase in utility of only one consumer or user. If a public goods can serve any number of users, it is a pure public good. It is a quasi-public good if there is a possibility of congestion, that is, overload. Pure public goods (Тривић, 2016, p. 397$415)$ are an abstraction and are the subject of most economic analyses. Public goods are characterised by two basic characteristics (Myles, 1995, p. 63):

1. non-excludability - no consumer can be excluded from the consumption process, apart from, perhaps, at the cost of infinitely high cost.

2. non-rivalry - consumption of a single consumer does not reduce the available quantity of a public goods to other consumers.

The principle or characteristic of non-excludability results in the inability of efficient control of consumption in price mechanism, as nobody can be excluded from their use. It stems from the characteristic of non-rivalry that any consumer may consume a maximum offered quantity of a public good, as own consumption does not affect the consumption of others. When all consumers want or must consume the total offer of a public good, the benefit or welfare of a consumer is dependent on the total offer of a public good.

A formal analysis of public good was started by Samuelson, who defined under which conditions the offer of public goods can be efficient. The topic of efficiency was further on developed by Lindahl (Lindahl, Erik significant papers - Just Taxation: A Positive Solution, Scope and Means of Monetary Policy, Studies in the Theory of Money and Capital ), who introduced personalised prices of goods. If is the unwillingness of households to discover their preferences due to desire for free use of things is added to this problem, things complicate significantly (Stiglitz, 2000, p. 198).

Although it was earlier mentioned that there is no possibility of influence on the level of consumption of others by personal consumption of public goods, overload can and does happen due to overuse in reality. Overload results in lower return that a public good offers every individual user during increased use of a public good. Such 
public goods are called quasi-public goods. The utility function of any consumer is the growing function of the level offer a public good and falling function of its use.

In the case of public goods, simultaneous collective consumption of all users (Vugrin, 2005, p. 316). This manner of consumption is not in accordance with the private nature of goods in Arrow-Debreu competitive nature model. The existence of public goods prevents reaching a balance on the competitive market (Nicholson, 2002, p. 345). This fact leaves space for state intervention in the area of offer of public goods and establishing equilibrium. Searching for an efficient solution, the state is faced with limited information, the most significant and most problematic of which lack of knowledge of households' preference for public goods..

\subsection{Optimum offer of public goods}

To perform a simple derivation of efficiency, let us suppose that a unique public good is offered and used by every consumer, that is, that the amount of consumption of any consumer equals the total offer of a given public good (Begg, 2001, p. 257). If there are $H$ consumers, marked with $h=1,2, \ldots, H$ utility function if every consumer is:

$$
U^{h}=U^{h}\left(x^{h}, G\right),
$$

where $x^{h}$ represents the consumption of consumers of $h$ vector of private goods, and $G$ is the offer of a public good. The assumption is that the total offer of the public good $G$ for utility function of every consumer points to the fact that it is a pure public good.

The assumption is, also, that the combination is $x^{h}, h=1,2, \ldots, H$ and $G$ that economy can offer is limited by production possibilities. Implicitly, the product set can be represented as

$$
\begin{array}{r}
F(X, G) \leq 0, \\
\text { where: } \quad X=\sum_{h=1}^{H} x^{h} .
\end{array}
$$

To achieve Pareto efficient solution, allocation $x^{h}, h=1,2, \ldots$, is implicit, $H$ and $G$ with maximised utility level of the first consumer and limitation of achieving suitable utility of other consumers from 2 to $H$, respecting the production capacities. Lagrange's function for this limitation is:

$$
\mathrm{L}=U^{1}\left(x^{1}, G\right)+\sum_{h=2}^{H} \mu^{h}\left[U^{h}\left(x^{h}, G\right)-\bar{U}^{h}\right]-\lambda F(X, G),
$$

where $\bar{U}^{h}$ represents the utility level achieved by consumers $h=2, \ldots, H$. Assuming that the required utility levels can be reached can be reached simultaneously, the required condition of component $x_{i}^{h}$ of $x^{h}$ is: 


$$
\partial L / \partial x_{i}{ }^{h} \equiv \mu^{h} \frac{\partial U^{h}}{\partial x_{i}^{h}}-\lambda \frac{\partial F}{\partial X_{i}}=0, \quad h=1,2, \ldots H,
$$

where $\mu^{h}=1$, for $h=1$. When determining the level of public goods, optimization by $\mathrm{G}$ gives:

$$
\partial \boldsymbol{L} / \partial G \equiv \sum_{h=1}^{H} \mu^{h} \frac{\partial U^{h}}{\partial G}-\lambda \frac{\partial F}{\partial G}=0 .
$$

Solving the equation 5 by $\mu^{h}$ and including in equation, 6 , the result obtained is:

$$
\sum_{h=1}^{H} \frac{\frac{\partial U^{h}}{\partial U^{h}}}{\partial x_{i}^{h}}=\frac{\frac{\partial F}{\partial F}}{\frac{\partial X_{i}}{\partial}}, \quad i=1,2, \ldots, n
$$

To explain expression 7, it is important to notice the left side, which is:

$$
\frac{\frac{U^{h}}{\partial G}}{\frac{\partial U^{h}}{\partial x_{i}^{h}}}
$$

representing the marginal rate of substitutability MRS between a public good and $i^{\text {th }}$ private good of consumers. The right side of expression 7 represents the marginal rate of transformation MRT between the public good and $i^{\text {th }}$ private good. Expression 7 is

$$
\sum_{h=1}^{H} M R S_{G i}^{h}=M R T_{G i} .
$$

Equation 9 represents Samuelson's rule by which Pareto efficiency is achieved when the marginal transformation rate between the public good and private good and sum for every private good equalizes with the marginal rate of substitutability between public good and private goods for every consumer (Landsburg, 2002).

The equation above can be compared with the corresponding rule in the case of efficient offer of two private goods $i$ and $\mathrm{j}$ :

$$
M R S_{j i}^{h}=M R T_{j i} \text { for all } i, j \text { and } h .
$$


The difference is the result of the fact that the additional unit of public good increases the utility of all consumers, so that social utility represents a sum of marginal utility of measured MRS. In optimum, this equals the marginal cost expressed by MRT. On the other hand the additional unit of private good increases the utility of a given consumer, and the optimum is reached when this utility is equalled with the marginal cost of production of this additional unit (Bannock, 1998, p. 198).

It is important that the degree of exclusion of consumers was not taken into account, and that the level of offer is considered as independent. Secondly, although the Samuelson rule seems very simple, its implementation is far from simple. For the rule to be applied and enforced, the assumption is that the state has a full control over the allocation of resources.

\subsection{Free use of public goods and overload}

Free disposal of the quantity of public goods that will be used is possible in the case where consumers' obligation to use the available amount of the public good. In this case, every consumer's obligation to use the available amount of public good to the maximum does not exist. In this case, every consumer decides how many public goods they will use in combined with private goods (Stojanović-Bašić, 2016, p. 239-251). Due to this correction of the above assumption, consumer utility function is:

$$
U^{h}=U^{h}\left(x^{h}, g^{h}\right),
$$

where $g^{h}$ where $g^{h}$ represents the consumption level of the public good by consumer $h$, and limitation $g^{h}<G$ for every $h$ added to 4 gives Lagrange function:

$\mathrm{L}$

$$
=U^{1}\left(x^{1}, g^{1}\right)+\sum_{h=2}^{H} \mu^{h}\left[U^{h}\left(x^{h}, g^{h}\right)-\bar{U}^{h}\right]-\lambda[F(X, G)]+\sum_{h=1}^{H} \rho^{h}\left[G-g^{h}\right] .
$$

The version if Samuelson rule that can be applied here is:

$$
\sum_{h=1}^{H} \frac{\frac{\partial U^{h}}{\partial g^{h}}}{x_{i}^{h}}=\frac{\frac{\partial F}{\partial F}}{\frac{\partial F}{\partial X_{i}}},
$$

with the condition that $\partial U^{h} / \partial g^{h}=0$, if $g^{h}<G$. Interpretation of expression 13 is that the marginal utility of use of a public good equals the marginal cost, but with the approval of non-use of public goods of individual consumers and arbitrary choice of the consumed amount.

For the majority of public goods overload is a public phenomenon (Gravelle, 1992, p. 213). Logically, overload decreases the utility that the consumers appropriate 
by using or consuming of the given public good, and the rule of efficiency is thereby modified (Bojović, 2004, p. 75-84).

In the presence of overload effect, utility is mostly expressed as dependent on the total offer of a public good, and the degree of use of the public good by the consumers. One of the approaches to the problem originates from Oakland (Oakland, William - great contribution in the area of public sector economy, public goods, welfare economy)

$$
U^{h}=U^{h}\left(x^{h}, g^{l}, g^{2}, \ldots g^{H}, G\right),
$$

with $\frac{\partial U^{h}}{\partial G}>0, \frac{\partial U^{h}}{\partial g^{h}} \geq 0$ and for $j \neq h$, it means that $\frac{\partial U^{h}}{\partial g^{j}}<0$. If consumers must use the total available amount of public good, then $g^{h}=G$ for every $h$ and the equation is:

$$
U^{h}=U^{h}\left(x^{h}, G, H\right) \text {. }
$$

If equation 15 is included into Lagrange function 12, the required condition of maximisation is obtained:

$$
\begin{gathered}
\sum_{j=1}^{H} \frac{\frac{\partial U^{j}}{\partial g^{h}}}{\frac{\partial U^{j}}{\partial x_{i}^{j}}}=\frac{\rho^{h}}{\lambda \frac{\partial F}{\partial X_{i}},} \quad i=1,2, \ldots, H, \\
\sum_{h=1}^{H} \frac{\frac{\partial U^{h}}{\partial U^{h}}}{\partial x_{i}^{h}}+\sum_{h=1}^{H} \sum_{j=1}^{H} \frac{\frac{\partial U^{j}}{\partial U^{j}}}{\partial x_{i}^{j}}=\frac{\frac{\partial F}{\partial F}}{\frac{\partial X_{i}}{2}}, \quad i=1,2, \ldots, n .
\end{gathered}
$$

In optimum $g^{h}<G$ for every $h$, then $\rho^{h}=0$ as well, and equation 16 points to the fact that consumption of each consumer should be extended until the private return is equalised with the sum of negative externalities that this causes to all consumers. In addition, the other expression in equation will equal zero, and it will express Samuelson's rule.

\subsection{Lindahl equilibrium}

Having derived Pareto efficiency criterion in nature with the presence of public goods, it is necessary to the question whether there is an economy in which competitive behaviour can result in an efficient solution. Equilibrium, which is explained in the standard Arrow-Debreu model will not result to an efficient solution by pricing 
mechanism in the presence of public goods. This is derived from the facts that consumers valorise the offer of a public good differently. Insisting on equal prices that must be paid for a unit of the given public good does not result in optimum.

The conclusion that Pareto optimum would be achieved if every consumer allocated their individual price for the given good. In this case, everyone would pay the price that reflects individual valuation of a good. Equilibrium established by means of individual prices is called Lindahl equilibrium (Đorđević \& Klincov, 2008, p. 403).

In a simple model with two consumers with one public good (Arnold, 1998), the central aspect of formulation is based on making a decision depending on the part of costs that the consumer must bear $\tau^{h}$. With the assumption that consumption increases infinitely with the limit $\tau^{h} \rightarrow 0$, equilibrium can be defined as a set of share in costs, $\left\{\tau^{l}, \tau^{2}, \ldots, \tau^{H}\right\}$, the sum of which must be equal to one and is of such characteristics that it forces all consumers to seek for the same amount of a public good. The main characteristic of this equilibrium is that it fulfils the Samuelson rule and is therefore a Pareto efficient solution, regardless of the fact that the existence of public goods is evident. In the case of existence of more public goods, share in the costs would be calculated for every good, and optimum would be reached in that case.

Let us assume that every consumer has the utility function:

$$
U^{h}=U^{h}\left(x^{h}, G\right), h=1,2,
$$

where $x^{h}$ is the consumption of a private good, and $G$ is the amount of the public good. If the amount of the public good that the consumer $h$ regards as necessary is represented with $g^{h}$, there is a limitation:

$$
x^{h}+\tau^{h} p_{G} G^{h}=\omega^{h} .
$$

In expression $19 p_{G} G^{h}$ is the total cost of supplying the market with a public good, and $\tau^{h}$ is the share of consumer $h$ in the cost. From the previous two expressions, consumer $h$ chooses $G^{h}$ to his utility:

$$
U^{h}=U^{h}\left(\omega^{h}-\tau^{h} p_{G} G^{h}, G\right) .
$$

The required condition for this maximisation is:

$$
\frac{U_{G}^{h}}{U_{x}^{h}}=p_{G} \tau^{h} .
$$

Solving equation 21 by $G^{h}$ generates Lindahl function of reaction:

$$
G^{h}=L^{h}\left(\tau^{h} ; \omega^{h}\right)
$$

which explains demand for public goods as a function of share in the cost and the initial income, that is, funds. 
The concept of Lindahl equilibrium (Lindahl, E. - formulated the concept of sequential economy and intertemporal equilibrium, gave solution to the problem of establishing prices of public goods) shows the way efficiency can be established in economy with public goods using individual prices. Personalized prices equalize individual valuation of the offer of the public good with production cost the way pricing mechanism in competitive nature is not able to equalize.

\section{Conclusion}

The aim of this paper is to represent the way of functioning of the competitive market and draw conclusions about the possibility of achieving general equilibrium. General equilibrium implies simultaneous achieving of Pareto efficient allocations on all markets in an economy. The characteristics of the equilibrium are reflected in the two theorems of welfare economy, pertaining to the basic statements about efficiency, and thereby the desirability of the competitive of competitive outcome.

The first theorem represents the formalization of Smith's understanding of efficiency by way of the invisible hand of the marketplace. According to the first theorem, competitive equilibrium is optimal, and according to the second theorem every optimum can be achieved as competitive equilibrium. Equivalence of Pareto efficient allocation and competitive equilibrium is the principal discovery of modern welfare economy (Pindyck, 2005, p. 368-392). Defining Pareto efficient solution, or improvement in Pareto terms, refers to the situation when the utility of one market player increases, but does not reduce to the others, which is the basic starting point of the normative welfare theory.

A significant contribution to the general equilibrium theory was given by Walras defining the eponymous law, by which the aggregate value of excessive demand must not be positive. Walras equation demands that the total value of excessive demands equals zero, that is, that excessive demands or excessive offers cannot exist on any market in economy in the case of total equilibrium. Violation of competitiveness of an economy can occur due to imperfect competition (when individuals have influence on pricing), presence of externalities or public goods.

Price mechanism is capable of bringing economy in the state of equilibrium only in the absence of externalities and public goods with public relations on the market. Pareto optimum could be achieved on the market where public goods are present only if each consumer allocated their individual price for a given good. In that case everyone would pay the price reflecting individual valuation of goods. Equilibrium established by means of individual goods is termed Lindahl equilibrium, and is expressed by Lindahl function of reaction: $\mathrm{Gh}=\mathrm{Lh}(\tau \mathrm{h} ; \omega \mathrm{h})$ explaining demand for public goods as a function of share in costs and initial income, that is, funds.

The concept of general equilibrium is extremely significant and great attention is devoted to it in scientific circles, and is therefore the subject of this paper. 


\section{Литература}

Arnold, A. R. (1998). Microeconomics, fourth edition. Chincinnati, Ohio: SouthWesern College Publishing.

Bannock, B. D. (1998). The Penguin Dictionary of Economics, sixth edition. London, England: Penguin Books.

Begg, F. D. (2001). Foundations of Economics. Berkshire, England: McGraw-Hill Publishing Company.

Bojović, V. (2004). Public assets: Characteristics, creation of demand for public goods and gratis users' problem. Anali Ekonomskog fakulteta u Subotici, (12), 75-83.

Brašić-Stojanović, J. (2016). Efikasnost u alokaciji zajedničkih resursa. Anali Ekonomskog fakulteta u Subotici, (36), 239-251.

Đorđević, D. i Klincov, R. (2008). Mikroekonomija. Banja Luka: Univerzitet za poslovne studije.

Ferček, I. (2003). Počela ekonomike. Osijek: Ekonomski fakultet u Osjeku.

Gravelle, R. (1992). Microeconomics, second edition. London: Longman Group.

Kesner-Škreb, M. (1993). Javna dobra. Financijska praksa, 17(3), 295-297. Retrieved on June 242019 from http://www.ijf.hr/pojmovnik/javna_dobra.htm.

Krtalić, S. (2005). Javna dobra: Što nam država pruža, a što želimo? Retrieved on June 202019 from http:/www.rifin.com/gosti-stranica/86-sandra-krtali-javna-dobra-tonam-drava-prua-a-to-elimo.

Landsburg E. S. (2002). Price Theory \& applications, fifth edition. United States of America: South-Western Thomson Learning.

Myles, G. D. (1995). Public Economics. Cambridge, UK: Cambridge University Press.

Nicholson, W. (2002). Microeconomic Theory - Basic Principles and Extensions, eight edition. United States of America: South-Western Thomson Learning,

Perloff, M. J. (2001). Microeconomics, second edition. United States of America: Addison Wesley Longman.

Pindyck, R. (2005). Microeconomics, fifth edition. New Jersey, United States of America: Prentice Hall.

Prirodni izvori i ekonomika okoliša (2005). Retrieved on May 62019 from https://blog.dnevnik.hr/pocela/2005/08/1615096361/prirodni-izvori-i-ekonomikaokolisa.html.

Samuelson, A., \& Nordhaus, W. D. (2007). Ekonomija. XIII izdanje, Zagreb: Mate. 
Stiglitz, E. J. (2000). Economics of the public sector. United States of America: WW Norton \& company Ltd.

Šagi, A. (1998). Mikroekonomski aspekti opšte kompetitivne ravnoteže. Anali Ekonomskog fakulteta u Subotici, (3), 57-68.

Trivić, N. (2010). Modeling the enterprise monopoly power. Anali Ekonomskog fakulteta u Subotici, (24), 33-42.

Trivić, N. (2016). Javna dobra. У Mikroekonomija, стр. 397-418. Bečej: Proleter.

Vugrin, M. (2005). Definiranje pojma javno dobro. Geodetski vestnik, br. 49/2005 - 3. Retrieved on June 202019 from http://www.geodetski-vestnik.com/49/3/gv49-3_416423.pdf.

Williams, W. (2003). Lessons from Adam Smith: Private Interest Public Good, Capitalism Magazine. Retrieved on June 202019 from

https://www.capitalismmagazine.com/2003/10/lessons-from-adam-smith-privateinterest-public-good/.

\section{Summary}

The concept of general equilibrium is extremely significant and draws a lot of attention in scientific circles. Research into this topic contributes to a more complete comprehension of functioning of mechanisms of the entirety of economy and serve as a basis for considering welfare economics and optimisation of contemporary market economies. The price mechanism is capable of bringing the economy into a state of equilibrium only in the absence of externalities and public goods, with competitive relations on the market. Pareto optimum on the market where public goods are present can only be achieved if every consumer assigns their individual price to a given public good. The concept of Lindahl equilibrium shows a way how efficiency can be established in economy public goods economy using individual prices. 